\title{
THE PROBLEM OF ARTHRITIS IN SWITZERLAND*
}

\author{
BY \\ A. BÖNI \\ Section on Physical Medicine, University Hospital, Zürich
}

The establishment of general measures of prophylaxis and therapy for arthritis has become in the last few years one of the serious concerns of the public and the authorities in Switzerland. Up to the present time, due to the relatively high standard of living of the Swiss working class, the labourers had been in a position to finance their treatment in most instances by their own means and with the help of their health insurance policies. As for the disabled and handicapped, the natural solution for them, in a predominantly agricultural population, was to be taken care of by their own families. The authorities, therefore, as represented by the Federal Health Department, have hitherto been given but small incentive to approach the problems of non-epidemic diseases.

Since the two world wars, however, with their sequels of high cost of living, of industrialization, and of rapid increase in the urban population, there has been a growing awareness of the problems with which the whole community is confronted due to the extent of chronic disabling diseases of the arthritic type.

Bruck (1939), former resident physician at the University Clinic for Physical Therapy in Zürich, produced interesting statistics about incidence and social effects of arthritis in Switzerland. The figures mentioned subsequently are taken from his publication. They are based mainly on a study of 93,750 reports of sickness among members of three organizations of national importance. These organizations, which include a typical portion of the average Swiss population, are: $(a)$ the Zürich Trade Health Insurance Co. $\dagger$ (reports of illness of 11,300 men and 8,100 women from 1929 to 1931) (see Table); (b) the St. Gall Christian Social Health Insurance Co. $\ddagger$ (reports of illness of 21,950 men and 29,400 women from 1929 to 1931); (c) the health service of the Swiss Federal Railways § (reports of

- Read at the First European Congress of Rheumatism at Copenhagen, Denmark, September 4 to $8,1947$.

Gewerbe Krankenkasse der Stadt Zürich.

St. Galler und Christlich-soziale Krankenkasse.

$\$$ Schweizerische Bundesbahnen.
33,000 employees from 1925 to 1935). Cases of rheumatoid arthritis, osteo-arthritis, and fibrositis were included in this study under the name of arthritis or chronic rheumatic diseases, without further specification of diagnosis. ${ }^{*}$ The statistical material thus collected particularly showed the influence of the three factors of occupation, age, and season on the incidence of the diseases of the arthritic group.

\section{Influence of Occupation, Age, and Season on Arthritis}

\section{Occupation}

Women.-The incidence of arthritis among the females of various occupations who reported sickness to the Zürich Trade Health Insurance Co. was as follows: $14 \cdot 29$ per cent. of the laundresses showed arthritic affections; 8.00 per cent. of the ironers; 7.43 per cent. of the housewives (this does not include maids); 3.57 per cent. of the typists; 2.33 per cent. of the seamstresses. Diseases and accidents connected with pregnancy and childbirth were not included in this calculation.

The female cases of the St. Gall Christian Social Health Insurance Co. presented a similar picture, with the highest incidence of arthritis appearing among the laundry workers (8.01 per cent.). The women working in agriculture ranked second in this series with an incidence of 5.39 per cent.

Men.-A study of the male cases of these two health insurance companies showed the following facts: (a) dyers and finishers had the highest incidence of arthritic conditions (8.08 per cent.); (b) porters ranked second with 7.89 per cent. incidence; (c) office clerks and weavers had an incidence of only 2.78 per cent. and 1.71 per cent. respectively.

Among the personnel of the Swiss Federal Railways, 15.41 per cent. of the outdoor workers, 8.5

\footnotetext{
* It would add materially to the value of such observations as are contained in this article if the three main types of chronic rheumatism were separated into rheumatoid arthritis, osteo-arthritis, and fibrositis, since they differ in aetiology and pathology and to some extent in treatment. Conclusions obtained from a combined grouping are apt to be misleading.-Editor.
} 
per cent. of those who worked part of the time indoors and part of the time outdoors, and 3.01 per cent. only of those who worked in offices were reported to be afflicted with some arthritic condition.

These figures stress the importance of environmental factors in the aetiology of arthritis. It seems evident, for instance, that the great dampness in the working rooms of laundresses, ironers, dyers, " and finishers accounts for the high incidence of arthritis in these vocations. Porters, farmers, and other outdoor workers, who are exposed both to trauma and inclement weather, are in a particularly unfavourable situation also.

On the other hand, low incidences are found among the typists, seamstresses, and office clerks who work in regulated atmospheric conditions with a minimum of mechanical strain. The low percentage incidence among weavers acquires full significance when it is recalled that most weaving mills are carefully air-conditioned, the air being maintained relatively dry and at a temperature of $22^{\circ}$ to $24^{\circ} \mathrm{C}$ : $\left(71 \cdot 6^{\circ}\right.$ to $75 \cdot 2^{\circ} \mathrm{F}$.).

TABLE

INCIDENCE AMONG MEMBERS OF ZÜRICH TRADE HEALTH INSURANCE CO., PERCENTAGE OF ALL SICKNESS

\begin{tabular}{|c|c|c|c|c|c|c|c|c|}
\hline \multicolumn{5}{|c|}{ * Men } & \multicolumn{4}{|c|}{ † Women } \\
\hline $\begin{array}{l}\text { Age, } \\
\text { yr. }\end{array}$ & $\begin{array}{l}\text { Arth- } \\
\text { ritis }\end{array}$ & $\begin{array}{l}\text { Tuber- } \\
\text { culosis }\end{array}$ & Others & Total & $\begin{array}{l}\text { Arth- } \\
\text { ritis }\end{array}$ & $\begin{array}{l}\text { Tuber- } \\
\text { culosis }\end{array}$ & Others & Total \\
\hline $\begin{array}{r}0-14 \\
15-29 \\
30-39 \\
40-49 \\
50-64\end{array}$ & $\begin{array}{r}0.17 \\
9.10 \\
15.95 \\
18.79 \\
18.59\end{array}$ & $\begin{array}{l}1.41 \\
0.91 \\
1.02 \\
0.42 \\
1 \cdot 23\end{array}$ & $\begin{array}{l}98 \cdot 42 \\
89.99 \\
83 \cdot 03 \\
80 \cdot 74 \\
80 \cdot 18\end{array}$ & $\begin{array}{l}100 \\
100 \\
100 \\
100 \\
100\end{array}$ & $\begin{array}{l}0 \cdot 51 \\
6 \cdot 27 \\
8 \cdot 72 \\
8 \cdot 88 \\
6 \cdot 37\end{array}$ & $\begin{array}{l}1.52 \\
1.22 \\
0.93 \\
0.95 \\
1.29\end{array}$ & $\begin{array}{l}97 \cdot 97 \\
92 \cdot 51 \\
90 \cdot 35 \\
90 \cdot 17 \\
92 \cdot 34\end{array}$ & $\begin{array}{l}100 \\
100 \\
100 \\
100 \\
100\end{array}$ \\
\hline $15-64$ & $14 \cdot 18$ & 0.92 & $84 \cdot 26$ & 100 & $4 \cdot 41$ & 1.04 & 93.95 & 100 \\
\hline
\end{tabular}

- Bruck, Index No. 63

$\dagger$ Bruck, Index No. 64

The Table shows a comparison between the incidence of arthritis, of tuberculosis, and of the other diseases with respect to the age of the patients. In contrast to tuberculosis, which appears much earlier, arthritis reaches its maximum of incidence in men and women of 50 to 60 years of age. This is the age at which, in addition to hormonal and metabolic disturbances, the external noxious agents have had time to develop their cumulative effects in the organism.
Seasonal Incidence.-There are two peaks of incidence, one in the spring and one in the autumn (see Figure). These peaks coincide with the periods of maximal occurrence of " colds", upper respiratory infections, tonsillitis, and streptococcal pharyngitis. This observation agrees with both the theory of streptococcal aetiology of arthritis and the theory of virus infection proposed by von Neergaard (" catarrhal rheumatism").

The results of the statistical studies on arthritis that were made in Switzerland concur with the opinion that infectious factors (seasonal incidence) and constitutional factors (age incidence), as well as environmental factors (vocational incidence), are of primary importance in the production of this condition.

\section{Socio-economic Effects of Arthritis in Switzerland}

Much more emphasis has been placed so far on the protection of the community against the effects of tuberculosis than against the effects of arthritis. It is interesting, therefore, to compare the damages of social significance brought about by each of the two diseases.*

General Incidence in Switzerland.-Expressed in percentages of the incidence of all diseases, the cases of arthritis represent 16.2 per cent., and the cases of tuberculosis only 0.45 per cent. The ratio of tuberculosis to arthritis is $1: 36$.

Unemployment due to Illness.-In the personnel of the Swiss Federal Railways, arthritis accounts for 16.4 per cent. of the total hours of absence due to illness, whereas tuberculosis accounts for only 3.7 per cent. of this time. In other words, $4 \cdot 4$ times more working hours are lost as a result of arthritis than as a result of tuberculosis.

* See also the June issue of the Annals, in which Dr. O. Savage discusses Dr. P. S. Hench's observations on this subject.-Bditor. 
Financial Losses.-Every year the Swiss national economy loses important sums of money because of tuberculosis but significantly more because of arthritis.

Financial Losses due to Tuberculosis.-Loss of work because of death due to tuberculosis amounts to 5,000,000 to $7,000,000$ Swiss francs yearly. Loss of work because of disability due to tuberculosis has amounted to $35,000,000$ to $40,000,000$ Swiss francs yearly. The federal government, the cantons, the communes, and the individuals have spent $18,000,000$ to $19,000,000$ Swiss francs yearly for treatment, hospitalization, caretaking, and tuberculosis organizations.

Financial Losses due to Arthritis.-Loss of work through sickness of short duration has cost $40,000,000$ to $45,000,000$ Swiss francs yearly; loss of work through premature retirement, $200,000,000$ to $220,000,000$ Swiss francs yearly; expenditures for treatment, $15,000,000$ to $20,000,000$ Swiss francs yearly.

It might be of interest also to compare the total financial losses imposed on the Swiss population by the two chronic diseases, arthritis and tuberculosis, with the relatively large sum of money expended by the country for purposes of military preparedness. The total loss due to tuberculosis is $58,000,000$ to $66,000,000$ Swiss francs yearly, which averages 15 Swiss francs per head above the age of 15 . The total loss due to arthritis is $225,000,000$ to $280,000,000$ Swiss francs yearly, which averages 85 Swiss francs per head above the age of 15 . The current expenditures for army purposes are $300,000,000^{\circ}$ to $400,000,000$ Swiss francs yearly. These facts compel us to conclude that arthritis, which provokes economic losses of a magnitude approaching that of the price paid for national security, must be a matter of national concern, and that this ailment deserves indeed to become the objective of a thorough and comprehensive programme of action.

\section{Outline of a Health Service for Arthritis}

The possibilities of influencing arthritic conditions are more numerous than generally is admitted, but a specific therapy is, of course, out of the question for the time being.

In the few cases where focal infection is obvious, focal sanitation and the use of the modern antibiotics are the natural measures of treatment. But in most other forms the basic infection (due to cocci or viruses) remains occult. The infectious agents in these cases seem very often to be ubiquitous and to become pathogenic under the influence of external insults, of general endocrine and metabolic changes, or of local disturbances in the organism. The first problem in dealing with these conditions is that of keeping under control the reactions of the organism to banal factors, such as cold, humidity, microtraumatisms, and ubiquitous micro-organisms. The goal of the treatment is to raise the non-specific resistance of the body, and the most efficient means for this purpose are, in our opinion, the general procedures of physical therapy: baths, fever therapy, light therapy, exercise, massage, and so forth. These are the weapons of what we term reaction therapy and reaction prophylaxis. We consider them of paramount general (and not only symptomatic) value in the approach to arthritic conditions, provided that they are applied by medical men of unquestionable experience in the field and by thoroughly trained therapists. The same physical agents, to which we must not forget to add the climatic and spa therapy, have also a beneficial regulating action on the hormonal and metabolic disturbances often observed in connexion with arthritis.

There is good reason to believe, therefore, that physical therapy, including also spa and climate therapy, which already plays the central part in the fight against arthritis in Switzerland, will continue to do so in the extensive programme of action that is being developed. Drug therapy, of course will not be neglected, but since it raises no special problem of organization, it will not be discussed further in this paper.

Any health service organization aiming at a comprehensive approach to the problem of arthritis, must have a division of preventive medicine and a clinical division working in close association with a specialized social service for arthritis.

Division of Preventive Medicine.-In the division of preventive medicine, both medical and social workers have to co-operate with the authorities in the establishment of: (1) more and better ways of eliminating the environmental factors which play a role in the development of arthritis (passive, or exposure prophylaxis); (2) more and better means of raising the power of resistance of the population against those same factors and the agents of banal infections (active, or reaction prophylaxis).

Passive ProphylaXIs.-The following activities of the division are connected with the first purpose (passive prophylaxis).

Surveys of Housing and Working Conditions.The elimination of dampness, the protection against draughts and sudden changes in temperature, are of over-riding necessity both in homes and in plants (modern concrete tenements are particularly objectionable in this respect). The workers, furthermore, must be protected against trauma, and particularly repeated microtrauma. This implies working under favourable postural conditions and with improved mechanical equipment. 
Vocational and Pre-vocational Series Examinations by Specialists in Arthritis.-The detection of the subclinical and threshold cases is here of paramount importance. It is senseless, for instance, to allow an asthenic youth or a boy with a spinal insufficiency to choose an occupation requiring heavy bodily work. It is equal nonsense to let girls with a history of an early attack of rheumatism earn their living as laundresses or kitchen-maids.

Active Prophylaxis. As regards the second purpose of the division (active prophylaxis) various measures, as previously mentioned, have been recognized to be of value in increasing the power of non-specific resistance of the organism. Such measures are, for instance, the practice of cold hydrotherapy and of heliotherapy, the use of the Finnish bath ("Sauna "), the practice of sport and gymnastics under medical control, and preventive annual visits in a spa or in a mountain resort.

It is the duty of officials and of private organizations, to see, with the help of the arthritis service, that the necessary facilities are provided and are used in accordance with sane medical concepts.

Clinical Division.-As soon as the arthritic condition becomes evident, treatment must be inaugurated with the utmost diligence. The general practitioner comes into action first, and he carries the widest responsibility for the patient's future. If he has any doubts concerning the diagnosis, or if he needs therapeutic advice, or if he fails to have the necessary therapeutic facilities, he must have every opportunity to refer his patient to a specialist or to an approved arthritis clinic.

The functions of the arthritis clinic will now be examined in some detail. They are those of diagnosis, treatment, and evaluation of vocational ability or of need for further care.

Diagnosis.-Anybody dealing with arthritic conditions knows how difficult it often is to establish an accurate differential diagnosis in this particular group. Off-hand diagnoses are always dangerous in the arthritic section. All modern facilities must be at hand if reliable examinations are to be made. The "mobile equipment" which proved to be useful for tuberculosis cannot be thought of for arthritis.

Treatment.-The direction of the treatment is assumed by the clinic only on the wish of the general practitioner, and to secure for the patient the benefits of more elaborate equipment. The physicians of the clinic have to administer the medical treatment, to prescribe the instructions for physical and occupational therapy, and occasionally to refer the patient to another department for, say, orthopaedics or $x$-ray therapy. The backbone of the therapeutic programme, indeed, is in most instances the application of physical therapy.
As regards the high costs of this form of treatment, it should be remembered that the best available therapy is in final analysis always less expensive than an incomplete or imperfect treatment.

Evaluation of Vocational Ability and of the Need of Further Care.-As an impartial party, disposing of an up-to-date diagnostic equipment, the arthritis clinic is in the best position to decide whether, when, and to what extent a patient can resume his former occupation. In several instances, furthermore, the question arises of a continuation of treatment or of a convalescent stay, in a sanatorium for arthritics, in a spa, or in a climatic resort. The answer to this can only be the result of careful medical assessment. This is a work of selection, in which the physician must keep in mind that the interest of the community as well as of the patient himself requires that those who do not need it, or for whom it may even be harmful, be restrained by persuasion from such therapy.

Social Service.-Social workers in this field must have a specialized training to be able to understand and to solve the very particular problems facing the arthritic.

A qualified report about the detrimental factors among a patient's housing and working conditions is of invaluable help to the physician in his dealing with many a case of arthritis. The social worker must be prepared to do this kind of investigation and to suggest the necessary measures of hygiene.

If the patient is unable to resume his former occupation on account of unavoidable detrimental conditions in his work or on account of permanent disabilities of his own, the social service has to help him find adequate new working opportunities and achieve his vocational rehabilitation.

In the cases where one of the following forms of therapy has been specifically indicated by the physician, the social service must be in a situation to provide the patient with all information concerning sanatoriums, spas, or climatic resorts, and to secure his admission in an ethical institution.

In keeping contact with present and past patients the social service has the best opportunity of collecting data and establishing statistics on the effects of the measures taken with its help or under its supervision. These findings, in turn, will be the rational basis for the subsequent activity of the entire arthritis organization.

\section{Concluding Remarks}

This is a far-reaching programme, the foundations of which are being built in Switzerland. Yet, it must be emphasized, in conclusion, that the whole plan is to be carried out on a voluntary basis. The liberty of the patient and the privileges of the 
general practitioner are to be respected in all circumstances. The arthritis service will place its resources and its qualified personnel at the disposal of those only-physicians, patients, communitieswho apply for its help.

\section{REFERENCES}

Bruck, M. “Bedeutung des Rheumatismus für Volksges undheitund-Wirtschaft." (1939). Edition Hans Huber. Bern.

von Neergaard, K. “Die Katarrhinfektion.” (1939). Edition Steinkopff. Dresden.

\section{Le Probléme de L'Arthrite en Suisse}

\section{CONCLUSIONS}

Pendant les dernières années la Suisse s'est occupée sérieusement à établir des mesures prophylactiques et thérapeutiques contre l'arthrite.

Les statistiques de deux compagnies d'assurance sur la santé dans le commerce à Zurich montrent, chez les femmes, une haute incidence d'arthrite chez les blanchisseuses, et une incidence peu considérable chez les couturières. Chez les hommes on trouve la plus grande incidence d'arthrite chez les teinturiers et les finisseurs, et la moindre incidence chez les employés de bureau et chez les tisserands. Parmi les employés des chemins de fer fédéraux suisses les employés de bureau sont plus rarement frappés d'arthrite que ceux qui travaillent au dehors.
Les statistiques montrent l'importance dans l'étiologie de l'arthrite d'étudier les influences externes: par example, les blanchisseuses et ceux qui travaillent dans des conditions d'humidité, et les facteurs, les fermiers et ceux qui travaillent au dehors, tous ceux travaillent dans des conditions peu favorables; de l'autre côté il y a les dactylographes, les couturières, les employés de bureau et d'autres chez qui l'incidence d'arthrite est assez basse.

Deux fois par an, en printemps et en été, on rencontre la majorité de cas d'arthrite. C'est en printemps et en été qu'on rencontre aussi la majorité de cas de " rhume ", des infections des voies respiratoires hautes, les angines, et les pharyngites streptococcales.

La proportion de la tuberculose à l'arthrite en Suisse est dans le rapport de 1 à 36 . On donne aussi les chiffres pour les pertes financières dues à ces maladies. On décrit un projet pour une organisation médicale contre l'arthrite, qui est divisée en deux parties: (1) la division de la médicine préventive, qui cherche à enlever les conditions externes qui contribuent à la haute incidence de l'arthrite, et à renforcer la resistance de la population aux maladies; (2) la plus grande responsabilité dans la division clinique reste sur le médecin praticien. On n'entreprend de traitement dans la clinique que sur son désir, et pour assurer pour le malade les avantages d'un équipement plus complet. On appuye sur l'importance des "social workers" pour garder le contact avec les malades.

Ce projet doit être accompli à choix libre. Les ressources et le personnel du service de l'arthrite seront mis à la disposition de ceux-médecins, malades, communautés-qui solliciteront de l'aide. 